\title{
砂漣の効果を考慮した海底摩擦係数の算定と 波高減衰について*
}

THE ESTIMATION OF FRICTION COEFFICIENT AT SEA BOTTOM BY CONSIDLERING THE EFFECT OF SAND RIPPLE AND THE CALCULATION OF WAVE DECAY

椹木亨**・岩田好一朗*** 一 久 保 雅 義**** By Toru SAWARAGI, Koichiro IWATA and Masayoshi KUBO

\section{1. 緒言}

海岸港湾構造物の設計波を的確に推定するためにはそ の地点の入射波の正確な算定が必要となることはいうま でもない.この浅海波の変形をもたらす一因として海底 摩擦の効果があげられる. $f=\tau_{b} / \rho u_{b}^{2}\left(\tau_{b}:\right.$ 海底摩擦力, $\rho:$ 流体の密度, $u_{b}$ : 海底での水粒子の水平方向の流速） で定義される摩擦係数 $f$ については Bretschneider ${ }^{1)}$ 以 来数多くの研究者 ${ }^{22 \sim 4}$ により実測的な研究がなされてき ているが，研究者によって図一1 に示すようにこの $f$ の值に大き な差異を示している．著者らも第 21 回海岸工学講演会論文集 ${ }^{5)}$ にお いて, 波によって発生する砂漣を 固定粗度とみなし, 梶浦の粗面乱 流境界層理論6) を用いて摩擦係数 $f$ の算定式を提案し，図一1に示 すように岩垣・柿沼 ${ }^{2), 3)}$, 土屋・山 口交らの現地における実測值と比 較を行っている.ここで図一1 中 の $d_{50}$ は砂の中央粒径, $d_{a v}$ 注平 均粒径, そして $R_{e T}$ は $\hat{U}_{b}{ }^{2} \cdot T / \nu$ $\left(\hat{U}_{b}\right.$ は境界層外縁の最大流速, $T$ は波の周期, $\nu$ は動粘性係数) で 定義されるレイノルズ数である. この図中の著者らの理論曲線およ び層流境界層理論の理論曲線につ いては前報を参照されたい. 先の 論文に扔て著者らはこの $f$ に 関する差異の原因の一つとして選 択的砕波 妾とりあげ，その効果
をも考慮して考察を行っているが，波浪の実測において はこの他にも波の不規則性に基づく非線形干涉, 方向分 散, 風および底質粒径の影響が加わっていると考えられ る. 特に図一1 亿示したよ与に各実測值はその底質に差 異があり，その底部粗度に大きな影響を与えると考えら れる. 砂漣の規模もまた後述するようにこの底質粒径と も密接な関係がある．しかしながらこの砂漣による海底 摩擦保数の変化のみをとらえるためには移動床実験によ って検証しなければならないが，実験室において実際の 海岸におけるような境界層の粗面乱流域を発生させるこ

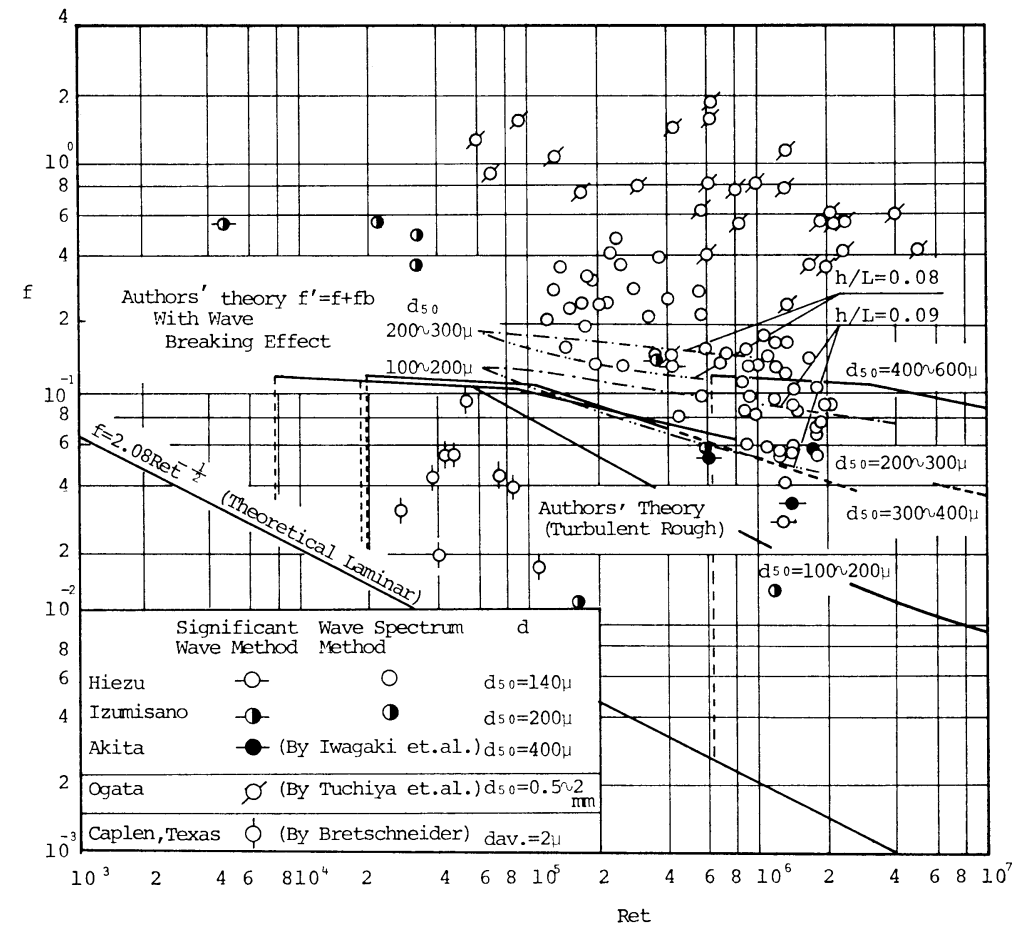

図一1 現地での実測摩擦係数と算定した摩擦係数との比較
$*$ 一部第 21 回海岸工学講演会にて発表 *** 正会員工博 大阪大学講師 工学部土木工学科
** 正会員工博 大阪大学教授 工学部土木工学科 **** 正会員神戸商船大学助教授 船貨輸送研究施設 
とは極めて困難であって, 著者らの先の論文においても 十分検証できなかった。

本論文においては，まず本間・堀川・鹿島らによって 提案された波による砂漣規模を表わすための定数を粒径 の 3 次曲線で近似して, 任意の粒径に対応した海底摩擦 係数の算定式を提案し, その提案式に対して, Zhuko$\operatorname{vets}^{8)}$ の移動床実験の結果をもって検討を加え, 移動床 での摩擦係数は, 固定床として算定した摩擦係数よりも 小さくなることを示し，あわせてそのための補正係数を 提示する.そしてこの新しく提案した海底摩擦係数を用 いて, 波高の減衰度を具体的例によって求め, 底部境界 層が粗面乱流の場合には層流の場合よりも波高減衰がか なり大きく，また Bretschneiderにより与えられてい る $f=0.01$ の場合ともかなり違った傾向を示すことを 明らかにした。

\section{2. 砂漣を固定粗度とみなした場合の海底摩擦 係数}

著者らは先に波浪により生じる砂漣の規模を示す実験 式として, 本間・堀川・鹿島 ${ }^{9} ら の$ 提案した式を用い, 梶浦 ${ }^{6}$ による境界層の層流から乱流への移行及び滑面か ら粗面への移行限界值から波高 $10 \mathrm{~cm} \sim 200 \mathrm{~cm}$, 周期 1 $\sec \sim 20 \mathrm{sec}, h / L=0.01 \sim 0.5$ ( $h$ : 水深, $L$ : 波長) の 諸元を有する一般的な海浜においては, 砂漣のできる場 合は底部境界層はほとんどの場合, 粗面乱流であること を明らかにした。したがって, 本論でも, 底部境界層は 粗面乱流として取扱うことにする.

梶浦の粗面乱流境界層理論を用いると底部での水粒子 の移動振幅 $\hat{U}_{b} / \sigma$ と砂漣波長 $\lambda$ の比によって, 抵抗則 は次のような二つの表示にわけることができる.すなわ ち,

$$
\tau_{b} / \rho=C \hat{U}_{b} U_{b}, C=\hat{C} e^{i \theta}
$$

で摩擦係数を定義するとき

$$
\left.\begin{array}{l}
\hat{C}=1.7\left(\frac{30 \lambda}{4 \eta}\right)^{-2 / 3} \text { for } \hat{U}_{b} / \sigma \lambda \leqslant 1 \\
\hat{C}=A\left(\frac{30 \hat{U}_{b}}{4 \eta \sigma}\right)^{-B} \text { for } \hat{U}_{b} / \sigma \lambda>1
\end{array}\right\}
$$

で与えられる.ここで, $\tau_{B}$ は底部摩擦, $\rho$ は流体の密 度, $\sigma=2 \pi / T, \eta$ : 砂漣の波高, $\lambda:$ 砂漣の波長, $\theta:$ 底部 流速と底面摩擦の位相のずれであり, 図一2 (b) で示さ れ, また $A, B$ は図一2 (a) に示される $\hat{C}$ を図の点線 で示すように折線近似して得た值で表一1のように表わ される. 図一2 において $Z_{0}$ は粗度高さであって, 砂漣 が形成されている場合, Motzfeld ${ }^{10)}$ の関倸式 $Z_{0}=4 \eta / 30$ が成立するものとする. 上のように定義された摩擦係数 $\hat{C}$ を用いて, 単位時間, 単位面積当りの底面摩擦によ るエネルギー逸散率を表わすと次のようになる.

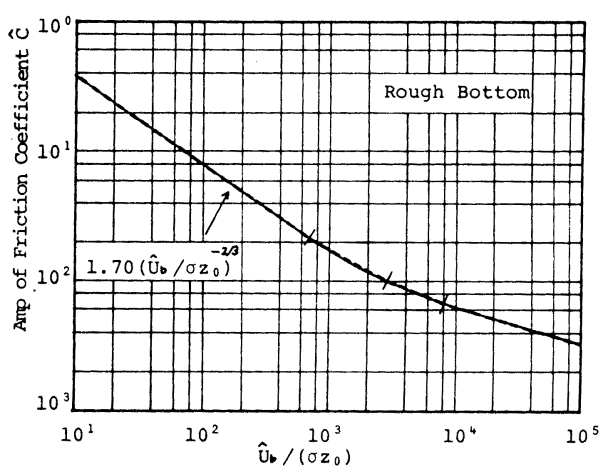

図一2（a）粗面乱流における摩擦係数の振幅 $\hat{C}$ とレイ ルズ数 $\hat{\boldsymbol{U}}_{b} / \boldsymbol{\sigma} \boldsymbol{Z}_{0}$ の関係（梶浦欣二郎, 1968)

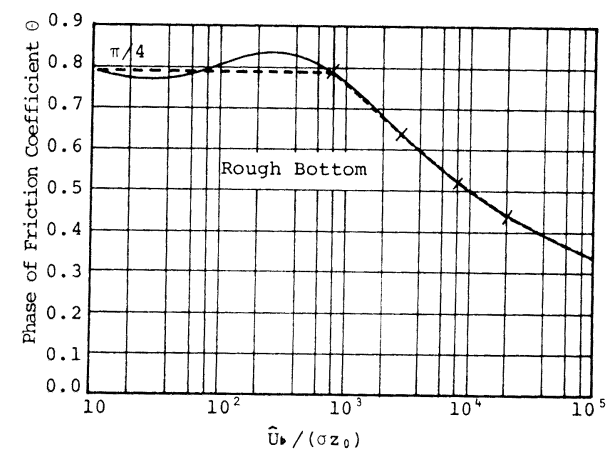

图一2（b）粗面乱流における摩擦保数の位相 $\theta$ とレイ ルス数 $\hat{\boldsymbol{U}}_{b} / \boldsymbol{\sigma} \boldsymbol{Z}_{0}$ との関係（梶浦欣二郎, 1968)

表一1 梶浦の粗面乱流境界層理論による $\hat{\boldsymbol{C}}$ およひ $\boldsymbol{\theta}$ と $\hat{\boldsymbol{U}}_{b} / \boldsymbol{\sigma} \boldsymbol{Z}_{0}$ の関係

\begin{tabular}{c|c|c}
\hline$\hat{U} / \sigma Z_{0}$ & $\hat{C}=A\left(\hat{U}_{b} / \sigma Z_{0}\right)^{-B}$ & $\theta$ \\
\hline$\sim 685$ & $1.7\left(\hat{U} / \sigma Z_{0}\right)^{-0.667}$ & $\approx \pi / 4$ \\
\hline $685 \sim 3 \times 10^{3}$ & $0.711\left(\hat{U} / \sigma Z_{0}\right)^{-0.536}$ & $1.558-0.266 \log _{10}\left(\hat{U} / \sigma Z_{0}\right)$ \\
\hline $3 \times 10^{3} \sim 8 \times 10^{3}$ & $0.24\left(\hat{U} / \sigma Z_{0}\right)^{-0.4}$ & $1.524-0.257 \log _{10}\left(\hat{U} / \sigma Z_{0}\right)$ \\
\hline $8 \times 10^{3} \sim 2 \times 10^{4}$ & $0.068\left(\hat{U} / \sigma Z_{0}\right)^{-0.26}$ & $1.287-0.196 \log _{10}\left(\hat{U} / \sigma Z_{0}\right)$ \\
\hline $2 \times 10^{4} \sim 10^{5}$ & $0.068\left(\hat{U} / \sigma Z_{0}\right)^{-0.26}$ & $1.092-0.15 \log _{10}\left(\hat{U} / \sigma Z_{0}\right)$ \\
\hline
\end{tabular}

$$
\langle E\rangle=\frac{\rho}{2} \hat{C} \hat{U}_{b^{3}} \cos \theta
$$

また従来の摩擦係数表示 $f$ を用いると上式の $\langle E\rangle$ は

$$
\langle E\rangle=\frac{4}{3 \pi} \rho f \hat{U}_{b}{ }^{3}
$$

で表わされるので，

$$
f=\frac{3 \pi}{8} \cos \theta \hat{C}
$$

といら関係が得られる.

一方, 波の特性と砂漣規模の大きさは, 本間・堀川・ 鹿島らによると 


$$
\left.\begin{array}{l}
\frac{\eta}{\lambda}=0.175\left(\frac{\lambda}{d_{0}}\right)^{0.19} \\
d_{0}=\frac{2 \hat{U}_{b}}{\sigma} \\
\lambda=\alpha^{\prime} T^{\prime} d_{0}^{1 \cdot 2 \gamma}
\end{array}\right\}
$$

によーてリえられてい\%。ここに

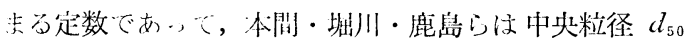
$=() .1 \sim 0.2 \mathrm{~mm}, d_{50}=0.2 \sim 0.3 \mathrm{~mm}, d_{50}=0.3 \sim 0.4 \mathrm{~mm}$

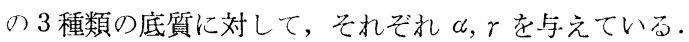

著者らは上述の $\alpha, \gamma$ の值を図一3に示すような 3 次 曲線で近似した（注 $d_{50}=400 \sim 600 \mu$ に対する $\alpha, r$ の 值は Inman の現地観測資料 ${ }^{11}$ から求めたものである). その結果, 次式に示すような近似式が得られる.ただし $d_{50}$ の単位は $\mathrm{cm}$ とする.

$$
\alpha=-389.4 d_{50}{ }^{3}+729.5 d_{50}{ }^{2}-313.3 d_{50}+40.7
$$

$$
\gamma=-82.66 d_{50}{ }^{3}+87.24 d_{50}{ }^{2}-28.62 d_{50}+3.28
$$

$$
\text { ここで, }
$$

$$
a=\left(\frac{0.01}{\pi}\right)^{\gamma} / \alpha, b=\gamma .
$$

なる変換を行えば,

$$
\frac{d_{0}}{\lambda}=a\left(\frac{R_{e T}}{\pi}\right)^{b}, R_{e T}=\frac{\hat{U}_{b}^{2} \cdot T}{\nu}
$$

なる関係が求まる.ただし式 (9) において 0.01 とある のは, 本来は $\nu$ であるが, $\nu=0.010 \alpha, r$ を求めてい るため ${ }^{91}$ ，それと対応させたためである. そこで式 (6) の $\eta, \lambda$ を式 (2) に代入し, 式 (5) を用いると, 海底摩 擦係数 $f_{\mathrm{fix}}$ (固定床の仮定を明示するため “fix”なる添 字を付ける) は

$$
\begin{gathered}
f_{\mathrm{fix}}=0.1155\left(\frac{\pi^{b}}{a}\right)^{0.1267} R_{e T^{-0.1267 b}} \\
\text { for } \pi\left(\frac{1}{a}\right)^{1 / b}<R_{e T}<\pi\left(\frac{2}{a}\right)^{1 / b}
\end{gathered}
$$

$$
\begin{gathered}
f_{\mathrm{fix}}=1.18 A \cos \theta\left\{0.0467\left(\frac{\pi^{b}}{a}\right)^{1.19}\right\}^{B} R_{e T^{-1.19} B b} \\
\mathrm{f}\left(\mathrm{rr} R_{e T}=\pi\left(\frac{2}{a}\right)^{1 / b} \ldots \ldots \ldots \ldots \ldots \ldots \ldots \ldots(12)\right.
\end{gathered}
$$

で表わすことができる。以卜より式（11），(12）中0ａ， bに式 (7)，(8) 及び式 (9) を，A，B,, に表一1に 示す值を用いると，任意の底質粒径 $d$ に対する海底摩摖 係数を求めることができる. しかしレイノルズ数 $R_{e T}$ が大きい所での砂漣規模についてはまだ未知の部分が多 く9，そのために式 (11)，(12) も適用限界をもつので限 界を越えた $f_{\mathrm{fix}}$ については図一1において点線で示し ておいた，ところで，式（7）（8）を導くのに用いた 4 種類の $d_{50}$ に対して上の関係から $f_{\mathrm{fix}}$ と $R_{\epsilon T}$ の関係 を求めると, 図一1 のように表わせる. 現地観測摩擦倸 数の值は研究者によって相当大きな差異があったが, 図 -1 で示すように底質粒径 $d_{50}$ およびそれに伴う砂漣規 模もその原因の一つと考えられる.

\section{3. 移動床実験による海底摩擦係数 $f$ の検証}

1.で述べたように現地の波高記録には, 波の不規則性 に基づく非線型干渉, 方向分散, 砕波, 風の影響が入。 てくるため, 現地の波高実測值より求めた $f$ の值と上 述の算定值を比較検証することは困難である.したがっ て, 上記の影響を受けない実験水槽で砂漣を形成して夹 験的に検証することが好ましい。

そこで著者らは Zhukovets ${ }^{8), 12)}$ の実験結果をもって, 先に提案した海底摩擦係数 $f_{\mathrm{fix}}$ の検証を行うことにし た.

Zhukovets は移動床水路で波高減衰実験を行い，2 点 閒の波高減衰から底部に砂漣が発生した場合の砂漣の形 状抵抗によるエネルギー損失 $\left\langle E_{b}\right\rangle$ をエネルギー平衡式 より式 (13)のように求めている.

$$
\begin{aligned}
\left\langle E_{b}\right\rangle= & -\frac{\left(E \cdot C_{G}\right)_{1}-\left(E \cdot C_{G}\right)_{2}}{l} \\
& -\left\langle E_{s}\right\rangle-\left\langle E_{\nu}\right\rangle \cdots \cdots \cdots \cdots
\end{aligned}
$$

$\gamma$ ここで $l$ は波高計の設置地点 1 と 2 の間 隔であり, $C_{G}$ は進行波の群速度, $E$ は 単位面積当りのエネルギー， $E_{s}$ は側壁 摩擦によるエネルギ一損失, $E_{\nu}$ は底部が 平たんな場合の底部摩擦および内部粘性 によるエネルギー損失, そしてく〉は 単位時間, 単位面積当りの平均を表わし ており, Zhukovetsは $\left\langle E_{s}\right\rangle$ および $\left\langle E_{\nu}\right\rangle$ をそれぞれ次式のように与えている。な おこれらについての詳しいことは文献 8)，12）夌参照されたい. 


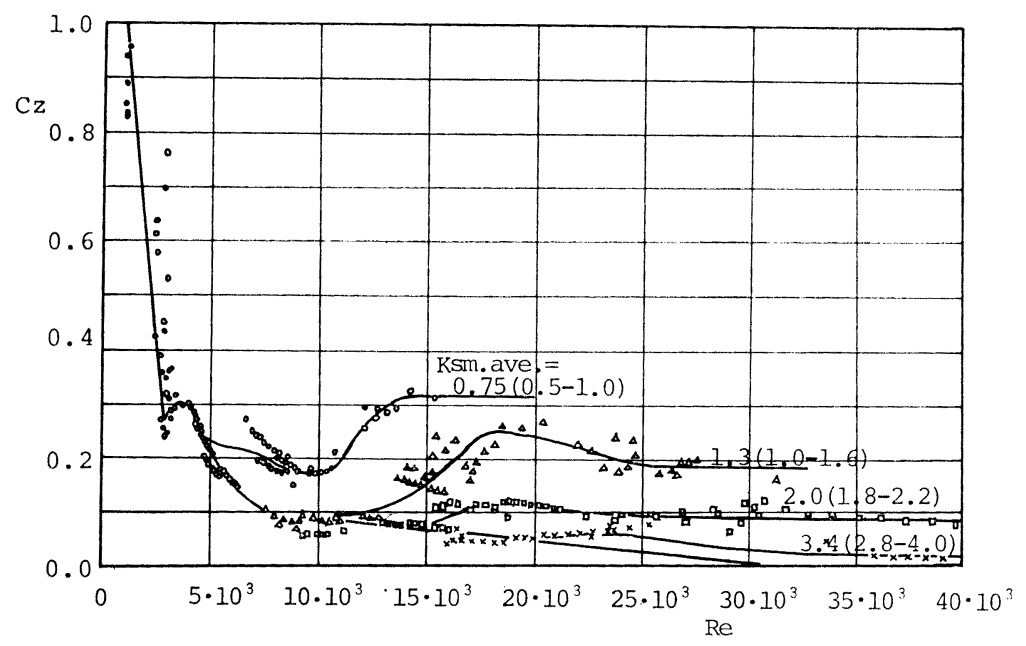

図-4 移動床実験から得られた抵抗係数 $C_{Z}$ とレイノルズ数 $\boldsymbol{R}_{c}$ との関係 (Zhukovets, A.M., 1963)

$$
\begin{aligned}
& \left\langle E_{s}\right\rangle=\frac{3.57 \rho h\left(V_{X}{ }^{2}+V_{Z}{ }^{2}\right)}{B_{W}} \sqrt{\frac{\nu}{T}} \cdots \cdots \cdot(14) \\
& V_{X}=\frac{H L}{\pi T h}+\frac{3 H^{2} \cosh k h}{4 T h \sinh k h} ; \\
& V_{Z}=-\frac{H L}{\pi T h}\left(\frac{\cosh k h-1}{\sinh k h}\right)-\frac{3 H^{2}(\cosh k h-1)}{8 T h \sinh ^{4} k h} \\
& \left\langle E_{\nu}\right\rangle=0.000112 k \rho c \sigma^{2} H^{3}+\frac{0.00025 \rho c k^{3} \sigma^{2} H^{4}}{\sinh ^{6} k h}
\end{aligned}
$$$$
\cdot\left(\frac{\sinh 2 k h \cosh 2 k h}{4 k}-\frac{h}{2}\right) \cdot \cdots \cdot
$$

ここで $B_{W}$ は水路幅, $k$ は波数, $c$ は波速, $h$ は水深,

$L$ は波長，Hは波高を示す. Zhukovets は波高減衰実験 から式 (13) の $\left\langle E_{b}\right\rangle$ を求めこの $\left\langle E_{b}\right\rangle$ を用いて次式で 定義される抵抗係数 $C_{Z}$

$$
C_{Z}=\frac{\left\langle E_{b}\right\rangle}{\frac{1}{2} \rho V_{g^{3}}}
$$

を算出し，それを図一4のようにまとめている。ここに $V_{g}$ は底部境界層外縁の流速を $1 / 4$ 周期平均した值で, Zhukovets によれば,

$$
V_{g}=\frac{\sigma H}{\pi} \operatorname{cosech} k h+\frac{3 k \sigma H^{2}}{8 \pi} \operatorname{cosech}^{4} k h
$$

で与えられる.これによると抵抗係数 $C_{Z}$ はレイノルズ 数 $R_{e}\left(=\frac{V_{g} \cdot H}{\nu \sinh k h}\right)$ で表わされるが，両者の関係はか なりばらついており，このばらつきをさらにZhukovets は相対粗度 $K_{s m}\left(=\frac{V_{g}^{2}}{2 g d_{50} \sinh \sqrt[4]{1+\eta / d_{50}}}\right)$ で整理して いる.また実験は層流域から乱流域まで広範囲に行って おり，たとえば $K_{s m}=0.75$ の場合には， $R_{e}<3 \times 10^{3}$ は層流領域であり， $R_{e}>15 \times 10^{3}$ は粗面乱流で, その間 は遷移領域となる.この図一4 に示した Zhukovets の 表示と著者らの表示との間には次の関係が成立する.
レイノルズ数:

$$
\begin{aligned}
R_{e} & =\frac{V_{g} \cdot I I}{\nu \cdot \sinh k h} \\
& \approx \frac{H}{\nu \cdot \sinh k h} \cdot \frac{2}{\pi} \cdot \dot{U}_{b} \\
& =\frac{2}{\pi^{2}} \cdot \frac{\left(l_{b}{ }^{2} \cdot T\right.}{\nu}=0.2 \cdot R_{e} T
\end{aligned}
$$

抵抗係数 :

$$
\begin{aligned}
C_{Z} & =\frac{\left\langle E_{b}\right\rangle}{\frac{\rho}{2} V_{g}{ }^{3}} \approx \frac{\left\langle E_{b}\right\rangle}{\frac{\rho}{2}\left(\frac{2}{\pi}\right)^{3} \hat{U}_{b^{3}}} \\
& \approx 3.29 f_{C Z} \cdots \cdots \cdots(19)
\end{aligned}
$$

相対粗度：

$$
K_{s m}=\frac{V_{g^{2}}^{2}}{2 g d_{50} \sinh \sqrt[4]{1+\eta / d_{50}}}
$$

以上のような関係を用いる上， 図一4 に示した Zhukovets の抵抗係数 $C_{Z}$ を先に著者 らが求めた摩擦係数 $f_{\mathrm{fix}}$ に換算することができるが, 2. で提案した著者らの海底摩擦係数 $f_{\mathrm{fix}}$ は粗面乱流の 境界層理論を用いているので, Zhukovetsの実験結果も 粗面乱流域での結果のみを用いて比較しなければならな い. Zhukovets が実験に用いた底質の粒度分布は $d>$ $0.25 \mathrm{~mm}$ が $50 \%, d>0.1 \mathrm{~mm}$ が $85 \%$ なので $d_{50}=$ $0.25 \mathrm{~mm}$ として著者らの方法で $f_{\mathrm{fix}}$ を算定した. とこ ろで式 (13) および式 (16) からわかるようにZhukovets は砂漣の形状抵抗のみによるエネルギー逸散 $\left\langle E_{b}\right\rangle$ を求 めているので,この $\left\langle E_{b}\right\rangle$ に基づいて算出された 図一4 の $C_{Z}$ (実験值そのものでなく実験曲線が示す值, 以後 これを実験值とよぶ）と著者らの $f_{\mathrm{fix}}$ との比較におい ては式 (13) の〈Evに対する補正をしなければならな い.そこでこの補正すべき摩摖係数 $f$,

$$
C_{\nu}=\left\langle E_{\nu}\right\rangle / \frac{1}{2} \rho V_{g}{ }^{3}=3.29 f_{\nu}
$$

をZhukovets の $C_{Z}$ から求めた $f_{C Z}$ に加えたものを $f_{\exp }$ として $f_{\mathrm{fix}}$ と比較した. そして, その比のレイ ノルズ数による変化を求めたのが図一5である。この場 合粗面乱流域が確立された領域といらことで，図一4の 実験值は $K_{s m}=0.75$ の とき $R_{e}>15 \times 10^{3}$ の実験值, $K_{s m}=1.3$ の場合 $R_{e}>17.5 \times 10^{3}$ の実験値, $K_{s m}=2.0$ の場合 $R_{e}>20 \times 10^{3}$ の実験值, $K_{s m}=3.4$ の場合 $R_{e}$ $>35 \times 10^{4}$ の実験值を用いている. 図一5によると, $K_{s m}$ が 0.75 の領域では計算結果と実験值とはよく一致する が， $K_{s m}$ が大きくなるにつれて, 計算によって求めら れた摩擦係数は実験結果より求められた值よりも大きく なっている.

この理由は明確ではないが， $K_{s m}$ が大きい場合は, 底 部流速 $V_{g}$ と粒径の相対比が大きい場合で, 浮遊砂が多 


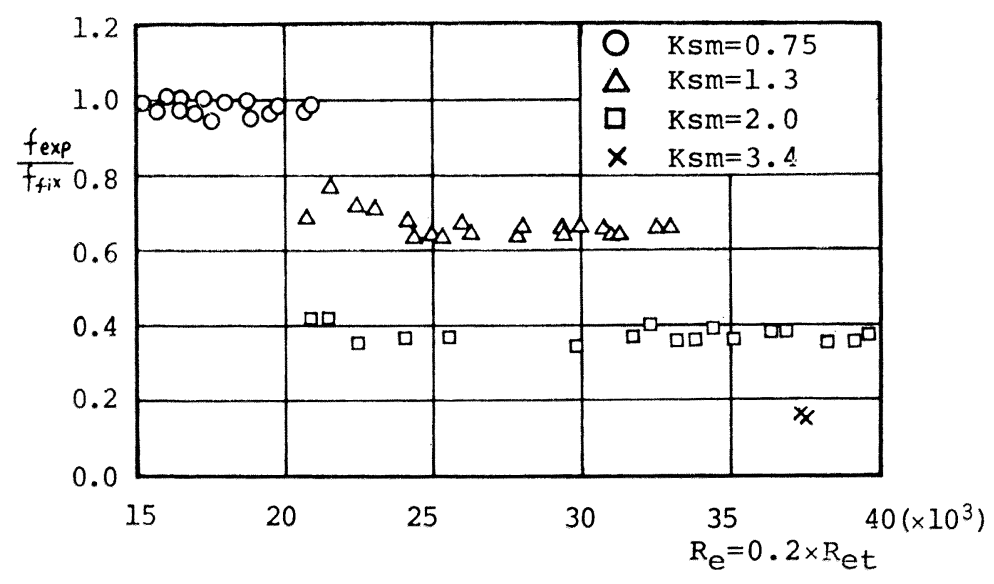

図一5 Zhukovets が実験から得た摩擦係数 $f_{\mathrm{exp}}$ と著者らの算定值 $f_{\mathrm{fix}}$ との比較
のように示すことができる.図一 6 においては $K_{s m}<0.75$ の領域 の実験值がないが，この領域の $K_{s m}$ は小さくそのため浮遊砂が 少なく固定床に近い状態になって いると考えられる．そのためこの 領域では水路床はほぼ固定床とみ なして補正係数 $F_{c}=1$ としてい る.

したがって他の底質粒径に対し ても，図一6 の補正係数 $F_{c}$ が使 かえるものとすれば，固定床にお ける摩擦係数 $f_{\mathrm{fix}}$ と移動床にお ける修正された摩擦係数 $f_{m}$ は次 のように求めることができる.

くなると考えられる.この浮遊砂は粗度によって生じる 境界層内の乱れを抢さえるように作用し，そのために移 動床に㧍いて底部摩擦は固定床とみなした場合よりも減 少するものと考えられる.

したがって実際の海岸における, 砂漣に基づく底部摩 擦係数は，先に砂漣を固定粗度として求めた式 (11) お よび式 (12) による摩擦係数 $f_{\mathrm{fix}}$ を相対粗度 $K_{s m}$ を考 虑して補正しなければならない。

図一5によると, 上述の $f_{\mathrm{fix}}$ と移動床における実験 值の比はレイノルズ数に関係なく $K_{s m}$ の值によってそ れぞれほぼ一定值をとることから，この比の $K_{s m}$ のみ の変化を求めてみると $K_{s m} \geqq 0.75$ の領域では 図一6

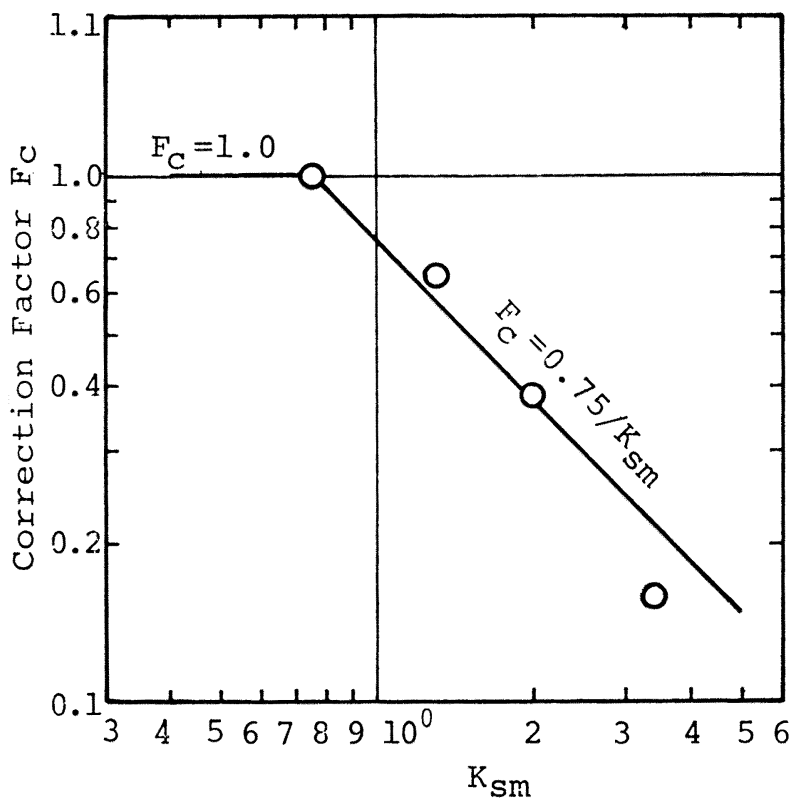

図一6 砂漣を固定粗度として求めた摩擦係数 $f_{\mathrm{fix}}$ の 相対粗度 $\boldsymbol{K}_{s m}$ による補正

$$
\begin{aligned}
& K_{s m}<0.75: f_{m}=f_{\mathrm{fix}} \\
& K_{s m} \geq 0.75: f_{m}=\left(0.75 / K_{s m}\right) f_{\mathrm{fix}} \\
& f_{\mathrm{fix}}=0.1155\left(\frac{\pi^{b}}{a}\right)^{0.1267} R_{e T^{-0.1267 b}} \\
& \text { for } \pi\left(\frac{1}{a}\right)^{1 / b}<R_{e T}<\pi\left(\frac{2}{a}\right)^{1 / b} \\
& f_{\mathrm{fix}}=1.18 A \cos \theta\left\{0.0467\left(\frac{\pi^{b}}{a}\right)^{1.19}\right\}^{B} \\
& \text { - } R_{e T^{-1.19 B b}} \text { for } R_{e T} \geqslant \pi\left(\frac{2}{a}\right)^{1 / b}
\end{aligned}
$$

ただし $K_{s m}$ が十分大きくなって $f_{m}$ が層流境界層理論 から求まる摩擦係数よりも小さくなった場合には $f_{m}$ と

しては便宜的に層流境界層の場合の摩擦係数を用 いるものとする.

\section{4. 波高減衰に及ぼす海底摩擦の効果}

次に移動床の特性を考慮した修正摩擦係数 $f_{m}$ によって一様傾斜面を波が進行する場合どの程度 波高が減衰するかを具体的に計算によって求めて みよう。ここで波高減衰に関するエネルギー平衡 式として次式が成立するものとする。

$$
\frac{d}{d x}\left(E \cdot C_{G}\right)=\left\langle E_{b}\right\rangle=-\frac{4}{3 \pi} \rho f \hat{U}_{b}^{3} \cdots
$$

ここに $E$ は単位面積当りの波のエネルギーで $\frac{1}{8} \rho g H^{2}$ で表わされるものとする. 底部の境界層 が層流の場合については，すでに土屋・井上 ${ }^{13)}$ よび Eagleson ${ }^{14)}$ らによって計算されているが, それによると摩擦係数は

$$
f=2.08 R_{e} T^{-1 / 2}
$$

for laminar boundary layer

と表わされる。これを式 (23) に代入して積分す 


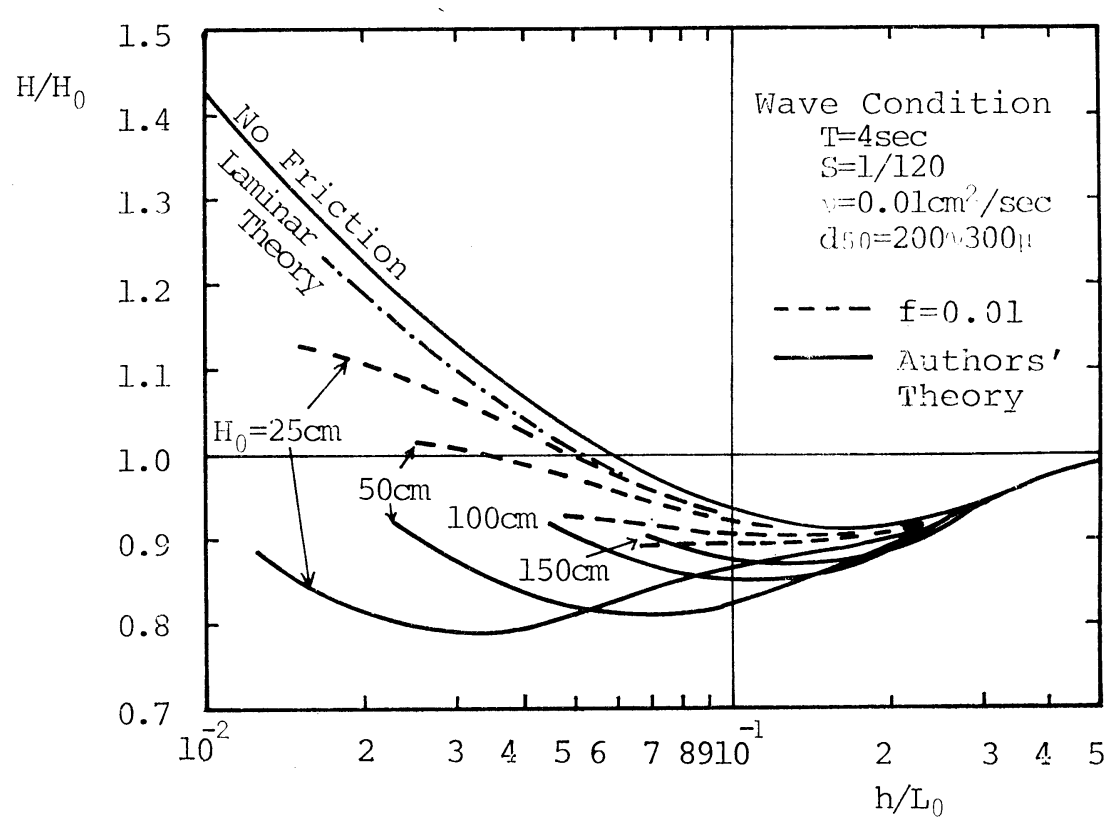

図一7底部摩擦を層流理論で評価した場合と粗面乱流理論で評価した場合の波高減衰の違い

れば, 次式のよらに進行波の波高変化が求められる.

$$
\begin{aligned}
& \frac{H}{H_{0}}=\left\{\frac{\left(1+\frac{2 \xi_{0}}{\sinh 2 \xi_{0}}\right) \tanh \xi_{0}}{\left(1+\frac{2 \xi}{\sinh 2 \xi}\right) \tanh \xi}\right\}^{1 / 2} \\
& \times \exp \left\{\frac{\pi}{\beta L_{0} S}\left(\operatorname{coth} \xi-\operatorname{coth} \xi_{0}\right)\right\} \\
& =F\left(\beta L_{0} S, \frac{h}{L_{0}}\right)
\end{aligned}
$$

ここで, $\xi=2 \pi h / L$ で $\xi=\xi_{0}$ において $H=H_{0}$ で, $\beta=$ $\sqrt{\pi / \nu T}, S$ は海浜勾配を示す. 式 (25) を $T=4 \mathrm{sec}, S$ $=1 / 120$ について求めると 図一7 の層流理論の曲線のよ うになる. 図一7 中で摩擦がない場合の值は Wiegel ${ }^{15)}$ が求めた Shoaling 係数である.この図から両者の差は 少なく, 摩擦による波高減衰効果は 2 3\% 程度である ことがわかる．またこの場合の摩摖による波高減衰効果 は波の周期が長くなるほどさらに小さくなっていく.

次に底部の境界層が粗面乱流の場合には, 摩擦係数と して式 (22) の修正摩擦係数 $f_{m}$ を用いれば式 (23)よ り波の進行に伴ら波高变化が求められる. しかしこの場 合は層流境界層の場合と異なり, 直接積分はできないの で，反復計算を行わなくてはならない. 式 (22) におい て, $a, b$ が粒径の関数で近似されているので, $d_{50}=200$

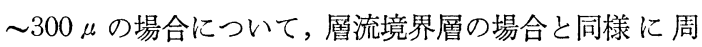
期 $T=4 \mathrm{sec}$, 海浜勾配 $S=1 / 120$ の条件において, 沖波 波高 $H_{0}=0.25 \sim 1.5 \mathrm{~m}$ に対する波高変化を求めたのが 図一7 の実線である.な打計算は式 (23) を差分化した 式 (26)

$$
H_{i+1}=\left(\frac{C_{G_{i}}}{C_{G_{i+1}}} \cdot H_{i}{ }^{2}-\frac{32 \cdot \Delta x}{3 \pi g C_{G_{i+1}}} \cdot f_{m i} \cdot \hat{U}_{b i}{ }^{3}\right)^{1 / 2}
$$

を用いて行っている.ここで, 添字 $i$ は場所を示してお り, $i$ 番目での波高 $H_{i}$ が与えられた場合 $H_{i+1}$ を仮定 し, $H_{i+1}$ と $H_{i}$ の平均值で摩擦項を評価して $H_{i+1}$ を求 め, これが先に仮定した值になるまで反復計算を行い, 収束したところで次の step へ進む. そこで最初に $h / L_{0}$ $=1$ の場所での沖波波高 $H_{0}$ および周期 $T$ を与えて, 上に述べた計算を繰り返してゆけば，一様海浜勾配での 波高変化が求まる.な拉計算は砕波点で打切っている. 砕波限界 ${ }^{16)}$ とては種々あるが，ここでは岸および佐伯 による

$$
\frac{H_{b}}{h_{b}}=5.68 S^{0.4}
$$

を用いている.この図から明らかなように粗面乱流の場 合には層流に比較して波高減衰はかなり大きいが，波高 が大きくなるとその効果は減少し, 砕波も沖の方で生に゙ るのがわかる．また従来 Bretschneider らによって提 案されている $f=0.01$ に対する波高減衰も計算してあ るが, この場合摩擦係数が $R_{e T}$ によって変化しないの で著者らの結果と比べ, かなり違った傾向を示してい る.

図一8 は波高減衰に及ぼす周期の影響を示したもので あって, 周期が短くなると砕波点は岸側で生じまた砕波 点での波高減衰の割合は大きくなるのがわかる.

最後に波高減衰に及ぼす海浜勾配の影響を求めたのが 図一9である.この図より沖波の特性が一定の場合でも 


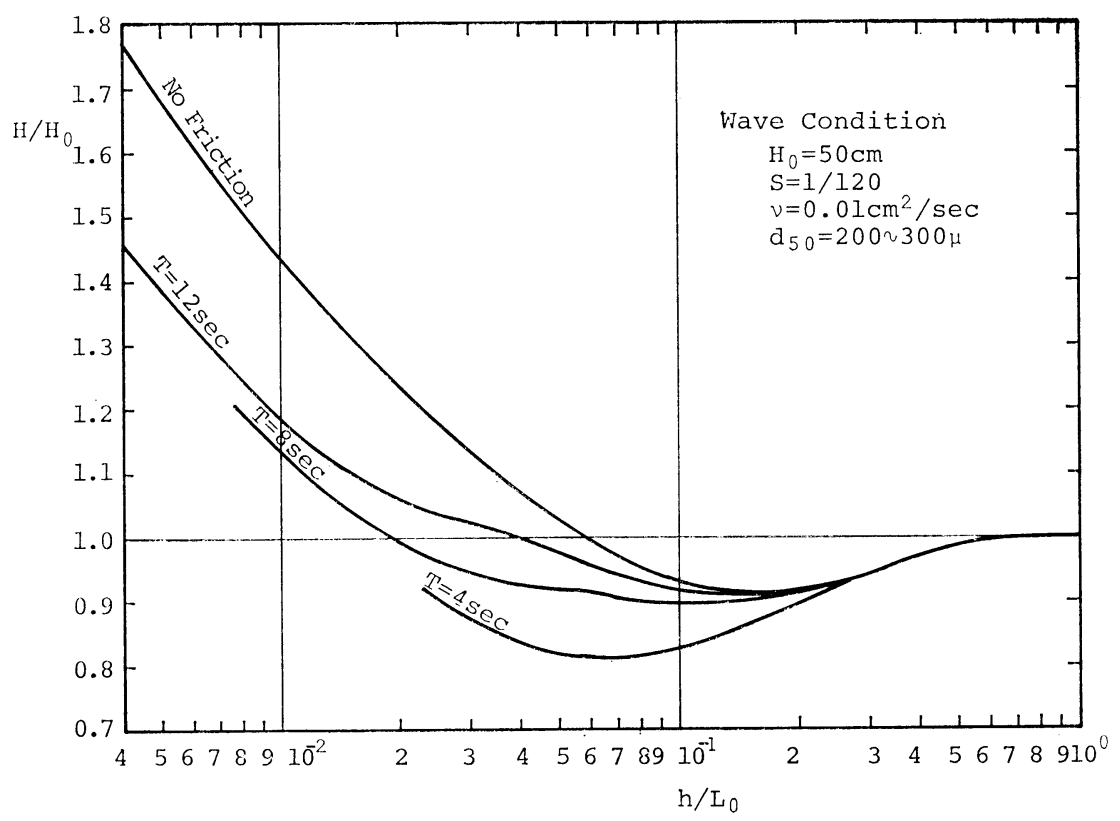

図一8 波高減衰に及ぼす周期の影響

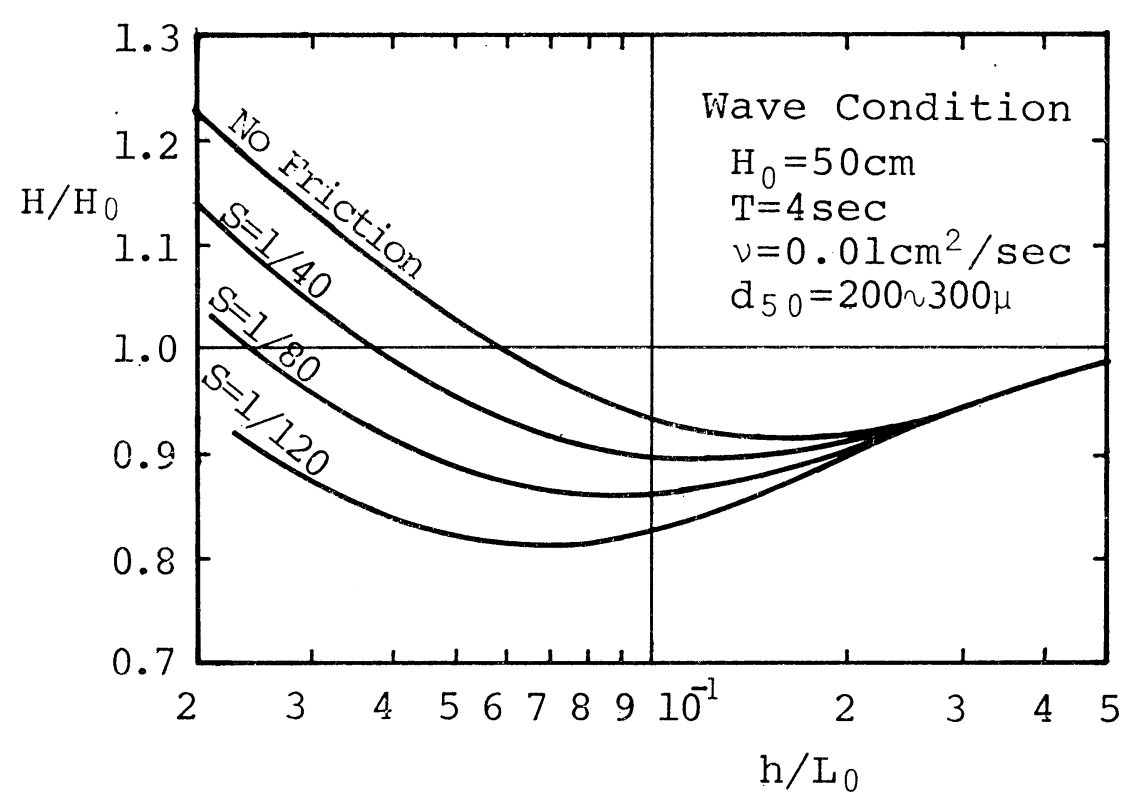

図一9 波高減衰に及ぼす海浜勾配の影響

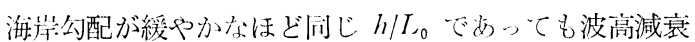
が大きいことが打ふ\%。

\section{5. 結語}

以上本論文では波により仯漣ができる場合，まずこれ 在周定粗度とみなして梶浦の粗面乱流理論を用いて摩擦 係数を理論的に算定するとともに，仯漣の規模を波の特
性，底質特性であらわすに市たって，本間・堀川らが示 した実験式中の定数を $d_{50}$ の三次の近似式で置き換えて 表示し，この砂漣の規模表示式と固定粗度とみなして導 いた摩擦係数を組合せて個々の砂粒径に対する摩擦係数 の一般表示式を得た.ついで Zhukovets が移動床で行 った波高減衰の実験から求めた摩擦係数こ砂漣を固定粗。 度と考えた場合の算定值とを比較し, 移動床実験による 摩擦係数は固定粗度し考えた場合の摩擦係数よりも小主 
くなることを明らかにして固定粗度として算定した摩擦 係数を修正し移動床の特性を考慮した摩擦係数 $f_{m}$ を提 案した。さらにこの著者らの提案した移動床に対する摩 摖係数 式 (22) を用いて, 一様傾斜面の海浜を波が進 行する場合の波高変化を求め, 底部が層流の場合よりも 減衰がかなり著しいことを示し，また海浜勾配がゆるや かで, 周期が短いほど波高減衰の度合が大きくなること を指摘した.

最後に本研究の計算において援助していただいた当時 大阪大学学生 中村順行君 (現 鹿島建設勤務) に感謝の 意を表する次第である.

\section{参考文献}

1) Bretschneider, C.L. : Field Investigation of Wave Energy Loss of Shallow Water Ocean Waves, B.E. B., Tech. Memo., No. 46, 1954.

2）岩垣雄一・杮沼忠男：浅海に打ける波浪スペクトルけ変 形々海底摩擦係数の推定について, 京都大学防苂研究所 年報第 8 号, pp. 379 396, 昭 40.3.

3）岩垣雄一・杮沼忠男・宮井 宏：現地海岸における海底 摩擦係数について, 第 12 回海岸工学講演会講演集, pp. 35 40, 1965.

4）上屋義人・山口正隆・中村俊一：大潟海岸における海底 摩擦係数と波浪特性との関係, 昭和 49 年度関西支部年講 概要集.

5）椹木 亨・岩田好一朗・久保雅義：現地海岸における海 底摩擦俰数に関する一考察, 第 21 回海岸工学講演会論文
集, pp. 7〜11, 1974.

6) Kajiura, K.:A Motion of the Bottom Boundary Layer in Water Waves, Earthquake Research Institute, 1967.

7）合田良尖: 不规則波の砕波指標について，第２０回海岸:士 学講演会論文集, pp. 571 577, 1973.

8) Zhukovets, A.M. : The Influence of Bottom Roughness on Wave Motion in a Shallow Body of Water, Bull. Acad. Sci., USSR, Geohys. Ser., No. 15611570, Transl. 943-948, 1963.

9）本間 仁・堀川清司・鹿島遼一：波による浮遊砂に関す る研究, 第 11 回海岸工学講演会講演集, 1964.

10) Motzfeld, H. : Die Turbulente Strömung an Welligen Wanden, Z. angew. Math. u. Mech., 24, pp. 225 253, 1937.

11）堀川清闬: 海最工学, pp. 217, 東京大学出版会, 1973 .

12) Zhukovets, A.M. : The Determination of the Energy Losses of Swells Resulting from Eddy and Kinematic Viscosity, Oceanology, No. 2, pp. 225 234, 1963.

13）土屋義人・井上雅夫：海底摩擦による波高減衰の基礎的 研究 (1), 第 8 回海率:学講演会講演集, pp. 19 24, 1961.

14) Eagleson, P.S. : Laminar Damping of Oscillatory Waves, J. Hydr. Div., A.S.C.E., 88, pp. 155 181, 1962.

15) Wiegel, R.L. : Oceanographical Engineering, pp. 514 $\sim 525,1964$.

16）椹木 亨: 砕波特論, 水工学シリーズ 73-B-2, 土木学会 水理委員会, 1973 .

(1975.9.18 - 受付) 